\title{
The Effect of Strategic Management Practices on SME Performances in Makassar, Indonesia
}

\author{
Sirajuddin Omsa ${ }^{*}$, Muhammad Ridwan, Muhammad Jayadi \\ Accounting Department, State Polytechnic of Ujung Pandang, Makassar, Indonesia \\ Email address: \\ sirajomsa31@gmail.com (S. Omsa), ridho70@yahoo.com (M. Ridwan), jayadaming@yahoo.com (M. Jayadi) \\ *Corresponding author
}

\section{To cite this article:}

Sirajuddin Omsa, Muhammad Ridwan, Muhammad Jayadi. The Effect of Strategic Management Practices on SME Performances in Makassar, Indonesia. American Journal of Theoretical and Applied Business. Vol. 3, No. 4, 2017, pp. 71-80.

doi: 10.11648/j.ajtab.20170304.12

Received: November 26, 2017; Accepted: December 22, 2017; Published: January 8, 2018

\begin{abstract}
The increasingly dynamic market conditions and competition among companies encourage business owners, including small and medium enterprises (SME) owners in Indonesia and in other countries to understand how SMEs can be maintained or enhanced their marketing and financial performances. In order to compete, strategic and policy management experts encourage companies, including SME to apply strategic management practices. This study aims to measure how strong the effect of the implementation of strategic management practices on the performance of SMEs in Makassar, Indonesia especially the performance associated with sales turnover, break even point (BEP), and profit. This research uses quantitative data with primary data source through interview process and questionnaire. The interview process was conducted with the head of the small and medium enterprises (SME) in Makassar, whereas questionnaires were distributed directly to 178 respondents by the survey officer. Of the 178 questionnaires distributed to the respondents, 158 of them $(88.76 \%)$ were eligible to be processed and analyzed. The results show that the strategic management practices such as strategic planning, strategic execution, and strategic evaluation have a positive and significant impact on sales volume, BEP achievement, and profits of SMEs, especially in medium-sized of enterprises. But the level of education does not serve as an important factor in moderating these strategic management practices against sales volume, BEP and profits. The study also shows that the determination of mission and strategic formulation (part of strategic management practices) have no significant effect on sales volume, BEP and profit. The results of this research are expected to contribute both to the academic community and to business actors, especially managers and/or owners of SME in Makassar. Another practical contribution is to provide inputs to policy makers such as Department of Cooperative and SME in Makassar, in order to develop the quality of SME to remain competitive and still exist in an increasingly dynamic and more competitive market.
\end{abstract}

Keywords: Strategic Management Practices, Sales Volume, Break Even Point (BEP), Profit, Small and Medium Enterprises (SME)

\section{Introduction}

As business competition is tighter and market conditions is more dynamic, many small and medium enterprises (SME) in Indonesia and in other countries develop their efforts to understand how SME can maintain or improve their marketing and financial performances. In order to be able to compete, some strategic and policy management experts have encouraged companies to implement strategic management practices. However, there is still an unresolved debate over the effect of strategic management practices on corporate performance. The results of previous research indicate that the relationship between the strategic management practices and corporate performances was inconsistent. Some argue that there is a strong relationship between the two variables, but no less believe that the two variables do not have a strong relationship [1]; [2]. As a result, until now, there is still a research gap in regard to the effect of strategic management practices on business performance.

This study aims to measure how strong the effect of strategic management practices on performance of SME in 
Makassar, Indonesia especially the performance associated with sales volume, break even point (BEP), and profit. The study also explores whether the level of education and the size of SME have a role in moderating the effect of strategic management practices on sales volume, BEP and SME's profit.

\section{Theoretical Background}

The literature review will be explained and discussed the characteristic of small and medium enterprises (SME), strategic management practices, and business performances.

\subsection{Characteristics of Small and Medium Enterprises (SME)}

Some agencies and regulators in Indonesia have defined small and medium enterprises (SME), such as the State Ministry of Cooperative and Small Medium Enterprises, Central Bureau of Statistics (BPS), Decree of Minister of Finance No. 316 / KMK.016 / 1994 dated June 27, 1994, and law number 20 Year 2008. This study is based on the definition of the Central Bureau of Statistics (BPS) related to SME using the amount of labor to distinguish between micro, small and medium enterprises. Central Bureau of Statistics (BPS) provides the definition of SME based on the labor quantity. According to BPS, micro, small, and medium enterprises are business entities that each has less than 5 labors, has 5 to 19 labors, and has 20 to 99 labors respectively. Furthermore, law number 20 year 2008 states that small business is a stand-alone productive economic enterprise, conducted by an individual or a business entity that is not a subsidiary or not a branch of a company owned, neither controlled or become part directly or indirectly from a large business. In general, SME's characteristics in Indonesia are as follows:

a. There is no clear separation between the owner and the manager of the company. Owner acts also as a manager of SME.

b. Capital is provided by an owner or a small group of capital owners.

c. The area of operation is generally local, although there are also export-oriented SME.

d. Have small size of the company, in terms of total assets, number of employees, and infrastructure.

e. The scale of business is small, labor-intensive, based on local resources, multiple actors, and spread across multiple locations.

\subsection{Strategic Management Practices}

According to [3] strategic planning and strategy management are similar. The first term is often used in the business world, while the former is often used in the academic world. In this research will be used the terminology of strategic management practiecs. [4] defines strategic management as a method of formulating and implementing long-term plans widely and flexibly to achieve organizational goals.

The key components of strategic management practice require answers to the question of where the future business direction is, where the current business will be, what business will be in the future, and what changes will occur in the business environment [5]. According to [6] and [3], key aspects of strategic management include environmental analysis, corporate mission setting, strategy formulation, strategy execution, strategy evaluation and control. [7] have observed that key aspects of strategic management include the company's long-term outlook, and defining the line of business to ensure the right strategy is applied to the company based on the environmental condition. This idea shows that the right strategy can help the organization to take advantage of emerging opportunities to minimize the threat posed by an unstable market environment.

Strategic management evolved in four different periods. Theoretically, the latest theory of strategic management is a resource-based view of the company [8] that focuses attention on the internal aspects of the company, where [9] characterizes representing an important research domain in the era of development the beginning of strategic management in the 1960s. Strategy pioneers such as [10] and [11] focus more on identifying best practices of companies that contribute to the their success. Researchers in this period have emphasized their opinion that the company's success is due to the role of internal factors and the company's unique competitiveness [9]. The argument that emphasizes the success of the company due to the internal factor is called by [12] as resource-based view (RBV).

In the $1970 \mathrm{~s}$, the focus of strategic management attention was on the external factor of the firm, known as industrial / organizational or I / O [13]. This theory was basically came from [14] and [15]. According to Porter in [16], in this era, corporate strategy is grouped according to the industrial structure. [14] and [15] believe that the performance of an enterprise is largely determined by external or industrial / organizational (I / O) factors that the company's management cannot fully control. In the third period, the focus of strategic planning theory shifted again to the internal corporate factors (RBV), characterized by an emphasis on competitive dynamics and the boundaries of the relationships between companies and their environment [17].

Compared to I / O, strategic management moves closer to internal corporate factors (RBV) and the competition among firms in a competitive environment [18]. In the fourth period, the company's resource-based view (RBV) became the focus of attention for the company in managing its strategy. Theoretically, the main premise of a resource-based view of a company addresses the fundamental question of how a company can achieve and sustain its competitive advantage [19].

In relation to strategic management practices, [20] describe four stages or strategic management processes, namely: (1) environmental scanning; (2) strategy formulation; (3) strategy implementation; and (4) evaluation and control. The strategic management process can be seen in the following figure 1 : 


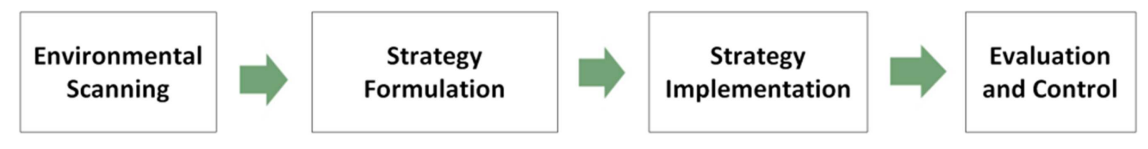

Figure 1. Strategic management process [20].

In the environmental scanning stage, the company performs an analysis of the company's internal and external environment. According to [3], the analysis of the external environment includes the economic, social, cultural, demographic, political, governance, legal, and technological environments. Furthermore, according to [20], the internal environment consists of structure, culture and resources. [21] also explain that core resources, capabilities, and competencies are part of the internal environment that affects companies. Meanwhile, according to [3] there are six major internal forces that affect an internal environment of the company that is management, marketing, finance / accounting, production / operation, research and development, and management information systems. In the stage of strategy formulation, the company determines the mission that is reason of the company to be established, the purpose or what and when a result is achieved, the strategy or plan to achieve the company's mission and objectives, as well as general policies or guidelines for decision-making. In the stages of strategy implementation, the company prepares a prorgam that is planned detailed activity, budget required to carry out activities, and the procedure to undertake activities. At the end of the strategic management stage, the company evaluates by comparing targets with real performance. Performance of companies that have not been in accordance with the target, will be corrected for the improvement in the next periods. Those strategic management stages will be the basis in determining the independent variables of the business strategy on the performance of SME.

\subsection{Business Performances}

The methods of business performance measurement still remain the subject of debate for both business practitioners and academic communities [22] and [23]. However, some researchers tend to agree that in general organizations may use performance measurement based on predetermined goals rather than using assessments of respondents, provided that the information presented is much more accurate [24] and [25]. According to [26], performance measurement methods can be divided into two types: objective and subjective measurement. Objective measurements include profit, sales volume, return on investment, break even point, and inventory turnover whose data are analyzed from financial statements, such as balance sheet and income statement. While the subjective measurement rely on the perception of firm managers or owners in regards to the business performance achieved.

The criticism on the objective measurement business performance is that its performance reports are difficult to access, confidential, incomplete, and often inaccurate [27]. In addition, in the objective approach, the amount of profit is often manipulated, and is difficult to compare among different business sectors. Furthermore, [24] suggest that objective measurements are unreliable because they are too general and tend to look backward rather than forward. Objective measurements are also more emphasizing on shortterm benefits rather than on long-term benefits. Consequently, managers or owners are difficult to understand the root causes of performance problems to make crossfunctional decisions in order to survive in uncertain business environments.

A study by [22] reveals that objective performance data is influenced by certain industry factors and therefore inappropriate to make cross-industry comparisons. As a consequence of these inaccuracies, [22] argue that previous researchers relied more on subjective company performance tracking due to difficulties in obtaining objective performance data, particularly in small and medium enterprises (SME). With regard to subjective performance measurement, performance information is provided in nonmonetary terms, such as sales volume, market share, customer satisfaction, employee turnover and new product development, relevant to survive in a competitive environment [28]. [29] argue that by subjective measurement, firm managers or owners are willing to give their perceptions about business performance, including their perception in regrads to the sensitive or confidential information needed by the frims to survive in a competitive and rapidly changing environment. [9] presents argument that the power of nonfinancial actions lies on their ability to provide insight into business processes, which in the long run is a better predictor of the future business performances.

There is little evidence from previous empirical studies that seek to evaluate strategic management in the domain of small business research [30]. Furthermore, [31] also agree that despite the wide recognition of the importance and significance of SME's contribution to employment, SME research still needs to be encouraged. [32] advocates the need for more systematic research aimed at revealing the true nature of strategic management in SME and their relationship to the marketing and financial performances.

In general, a review of the literature on strategic management in developing countries shows that focused research on the impact of strategic management practices on the SME's marketing and financial performances is still limited. There was a study conducted in South Africa on the subject, but the research did not specifically analyze the relationship between strategic management practices and SME's marketing and financial performances. [33], for example, examines the strategic management processes in the retail sector. [34] evaluates business development strategies in the SME sector. Furthermore, [4] examines the general 
strategic management processes. Whereas [35] examines the relationship between strategic planning and entrepreneurial orientation in the financial and business sectors. Meanwhile, [36] focuses his research on strategic planning in the small and medium-sized retail sector, as well as [37] conducts study on the relationship between entrepreneurship and SME's performances in South Africa. Although there is a considerable amount of research related to SMEs, but the research that links between strategic management practices and its impact on SME's marketing and financial performances is still very limited.

The researchs that have aims to analyze the effect of strategic management practices on SME performances give important way because this type of reseach can broaden valuable konwledge for the SME's owners or managers in order to have intiation on how strategic management practices can offer the good mechanism that may increase their SME's performances.

In this research, business performances defined as SME's performances in marketing (sales volume), and in finance (break even point \& profit. These three business performances were selected based on the ease of investigating the SME's performances. In addition, based on the limited previous emperical findings in regards to the relationship between strategic management practices and SME's performances, this research aims to analyze the effect of strategic management practices on SME's performance in Makassar.

\section{Research Methods}

Research methods described the population and samples, research hypotheses, research conceptual framework, and hypothesis testing procedures.

\subsection{Population and Samples}

This research uses quantitative data with primary data source through interview process and questionnaire circulation. The interview process was conducted with the head of cooperative and small and medium enterprises (SME) of Makassar. The population of this study is the owner of the SME in Makassar which amounted to 8,419 units. Prior to circulating questionnaires, first selected samples using Slovin formula with inaccuracy slack due to sampling error tolerated 1 to $10 \%$. The formula used to determine the sample is:

$$
n=\frac{N}{1+a^{2}}
$$

Remarks:

$\mathrm{n}$ : number of samples

$\mathrm{N}$ : number of population

a: percentage of inaccuracy lees due to intolerable sampling errors. By using 7.5\% precision of 8,419 SMEs in
Makassar, the number of samples can be calculated as follows:

$$
\mathrm{n}=\frac{8.419}{1+8.419 \times(0,075)}=177,76 \text { counted as } 178
$$

Therefore, the number of respondents expected to fill the questionnaire is 178 people. Of the 178 number of questionnaires distributed, $158(88.76 \%)$ fill in complete items of questions and statements, hence it is worth to be analyzed. The analysis unit in this study is the owner or manager of the SME. They are identified by position in the business who are responsible for strategic management practices. In the demographic section, respondents have been asked for information regarding their positions in business, gender, age, educational level, year of establishing, number of employees, type of business, and business location. Furthermore, structured questionnaires are used to track the opinions of respondents on the strategic management practices and marketing and financial performances of the SME.

\subsection{Research Hypothesis}

In order to support the aforementioned research objectives, the research hypotheses are formulated as the following:

Hypothesis 1: Strategic management practices have significant effect on SME sales volume.

Hypothesis 1a: Strategic management practices have a significant effect on SME sales volume moderated by the company size.

Hypothesis 1b: Strategic management practices have significant effect on SME sales volume moderated by the level of SME owners education.

Hypothesis 2: Strategic management practices have significant effect on the accelerated achievement of SME break even point (BEP).

Hypothesis 2a: Strategic management practices have significant effect on accelerating the achievement of SME breakeven point (BEP) moderated by company size.

Hypothesis 2b: Strategic management practices have significant effect on the accelerated achievement of SME break even point (BEP) moderated by the level of SME owners education.

Hypothesis 3: Strategic management practices have significant effect on the achievement of SME profit.

Hypothesis 3a: Strategic management practices have significant effect on SME profit achievement moderated by company size.

Hypothesis 3b: Strategic management practices have significant effect on the achievement of SME profit moderated by the level of SME owner education.

\subsection{Research Conceptual Framework}

Based on the above hypotheses, the research conceptual framework can be described as follows (Figure 2). 


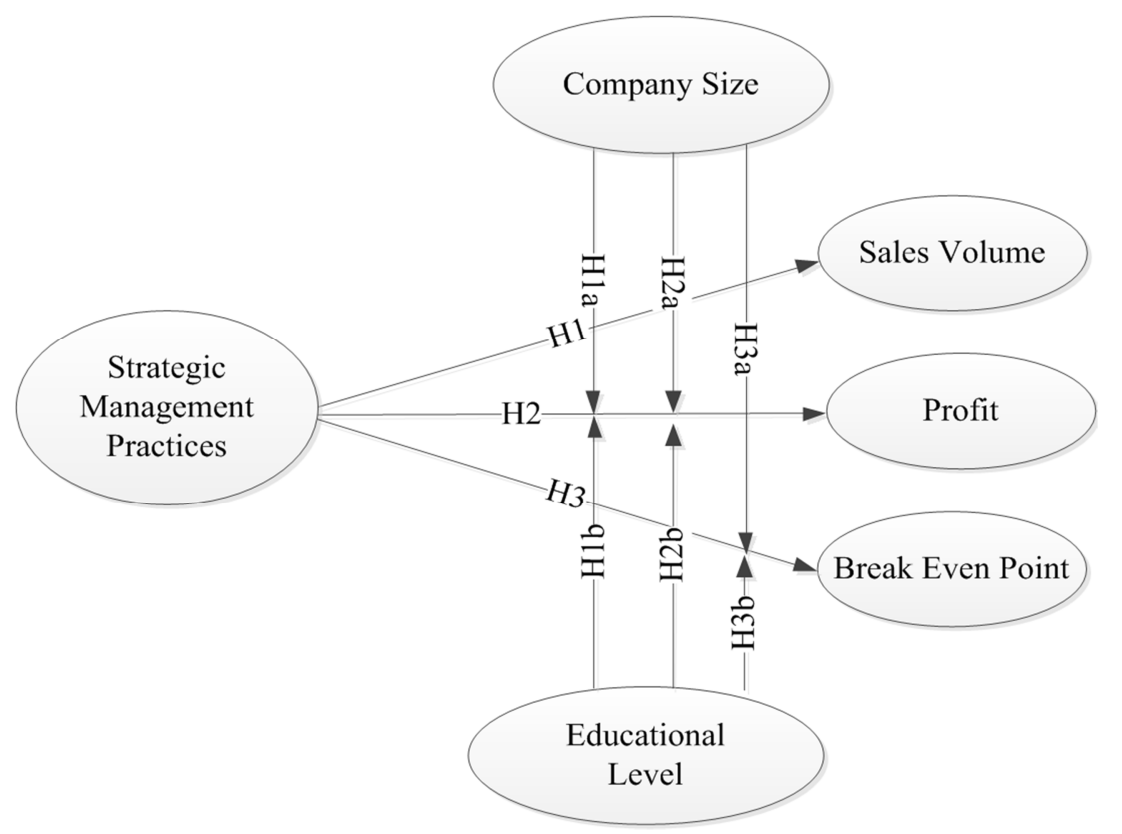

Figure 2. Research conceptual framework.

The variables of strategic management practices consist of business strategy planning, corporate mission setting, business strategy formulation, business strategy execution, and business strategy evaluation \& control. Furthermore, company size (as moderating variable) consists of small size and medium size. The level of education also as a moderator variable consists of elementary school, junior high school, senior high school, diploma, and bachelor.

\subsection{Hypothesis Testing Procedures}

Prior testing the hypotheses, it is necessary to teste the validity, reliability, autocorrelation, and multicollinearity of the items used in the questionnaire.

\subsubsection{Validity Testing Results}

From the instrument validity test, it indicates that the whole item is valid because it has a correlation coefficient $(\mathrm{r}) \geq 0.30$ and the significant value of all instruments is below $\alpha=0.05$ as shown in Figure 3. Therefore, all items in this research instrument can be used for further analysis.

Correlations

\begin{tabular}{|c|c|c|c|c|c|c|c|}
\hline & & RENSTRA & MISI & RUMUSTRA & LAKSTRA & EVASTRA & KINERJA \\
\hline \multirow[t]{3}{*}{ RENSTRA } & Pearson Correlation & 1 &, $623^{* *}$ &, $620^{\star *}$ &, $620^{* *}$ &, $584^{* *}$ &, $634^{\star \star}$ \\
\hline & Sig. (2-tailed) & &, 000 & ,000 &, 000 & ,000 & ,000 \\
\hline & $\mathrm{N}$ & 59 & 59 & 59 & 59 & 59 & 59 \\
\hline \multirow[t]{3}{*}{$\mathrm{MISI}$} & Pearson Correlation & $623^{* *}$ & 1 & $630^{* *}$ & ,419** &, $549 * *$ & $497^{\star \star}$ \\
\hline & Sig. (2-tailed) &, 000 & & ,000 & ,001 & ,000 & ,000 \\
\hline & $\mathrm{N}$ & 59 & 59 & 59 & 59 & 59 & 59 \\
\hline \multirow[t]{3}{*}{ RUMUSTRA } & Pearson Correlation & 620 , & ,630** & 1 &, $524^{* *}$ & $804^{* *}$ &, $581^{\star *}$ \\
\hline & Sig. (2-tailed) &, 000 &, 000 & & 000 & ,000 & ,000 \\
\hline & $\mathrm{N}$ & 59 & 59 & 59 & 59 & 59 & 59 \\
\hline \multirow[t]{3}{*}{ LAKSTRA } & Pearson Correlation & $620 * *$ & $419^{* *}$ &, $524^{\star *}$ & 1 & $449^{\star *}$ & $689 * *$ \\
\hline & Sig. (2-tailed) &, 000 & ,001 & ,000 & &, 000 & ,000 \\
\hline & $\mathrm{N}$ & 59 & 59 & 59 & 59 & 59 & 59 \\
\hline \multirow[t]{3}{*}{ EVASTRA } & Pearson Correlation &, $584^{* *}$ &, $549 * *$ & $804^{\star *}$ &, $449^{* *}$ & 1 &, $567^{\star *}$ \\
\hline & Sig. (2-tailed) & ,000 & ,000 &, 000 &, 000 & & ,000 \\
\hline & $\mathrm{N}$ & 59 & 59 & 59 & 59 & 59 & 59 \\
\hline \multirow[t]{3}{*}{ KINERJA } & Pearson Correlation & $634^{* *}$ & $497^{* *}$ &, $581^{\star *}$ & $689^{* *}$ &, $567^{* *}$ & 1 \\
\hline & Sig. (2-tailed) & ,000 & ,000 &, 000 &, 000 & ,000 & \\
\hline & $\mathrm{N}$ & 59 & 59 & 59 & 59 & 59 & 59 \\
\hline
\end{tabular}

${ }^{* *}$. Correlation is significant at the 0.01 level (2-tailed).

Figure 3. Validity testing results. 


\subsubsection{Reliability Testing Results}

The next step after testing the validity is conducting the reliability test. The results of the reliability test can be seen in Figure 4. Figure 4 shows that the six variables are realibel because its Cronbach Alpha value is greater than 0.6 that is 0.887. Therefore, all items are reliabile, hence, the questionnaire used in this study can be considered as an instrument for measuring.

Reliability Statistics

\begin{tabular}{|c|c|c|}
\hline $\begin{array}{l}\text { Cronbach's } \\
\text { Alpha }\end{array}$ & $\begin{array}{c}\text { Cronbach's } \\
\text { Alpha Based } \\
\text { on } \\
\text { Standardized } \\
\text { Items }\end{array}$ & $\mathrm{N}$ of Items \\
\hline ,887 & ,895 & 6 \\
\hline
\end{tabular}

Figure 4. Reability testing results.

\subsubsection{Autocorrelation Testing Results}

The results of the autocorrelation test can be seen in Figure 5. Durbin Watson's value in Figure 5 shows the magnitude between -2 and 2 , hence, can be concluded that there is no autocorrelation symptoms in this study.

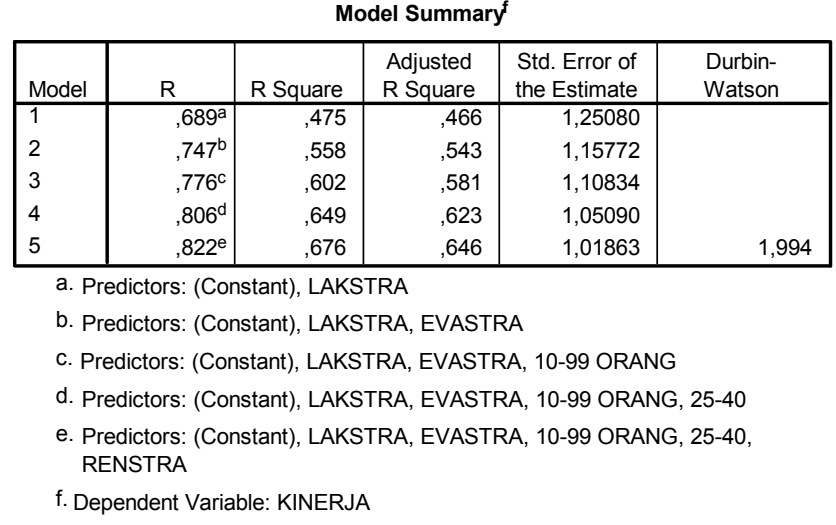

Figure 5. Autocorrelation testing results.

\subsubsection{Multicollinearity Testing Results}

The Figure 6 shows that the VIF value is $<10$, hence can be concluded that there is no multicollinearity symptoms in this study. In the $5^{\text {th }}$ model obtained, 5 variables significantly affect the company's marketing and financial performances with a significance level of $5 \%$. The variables are the strategic planning, strategy implementation, strategy evaluation \& conrol, number of employees between 10-99 people and age of owners (managers) between 25-40 years. Of the 5 variables, only medium size enterprises (10-99 labors) variable that has negative effect on firm performances.

Coefficients $^{\mathrm{a}}$

\begin{tabular}{|c|c|c|c|c|c|c|c|c|}
\hline \multirow[b]{2}{*}{ Mod } & & \multicolumn{2}{|c|}{$\begin{array}{l}\text { Unstandardized } \\
\text { Coefficients }\end{array}$} & \multirow{2}{*}{$\begin{array}{c}\text { Standardized } \\
\text { Coefficients } \\
\text { Beta }\end{array}$} & \multirow[b]{2}{*}{$t$} & \multirow[b]{2}{*}{ Sig. } & \multicolumn{2}{|c|}{ Collinearity Statistics } \\
\hline & & $\mathrm{B}$ & Std. Error & & & & Tolerance & VIF \\
\hline \multirow[t]{2}{*}{1} & (Constant) & 5,960 & ,861 & & 6,923 &, 000 & & \\
\hline & LAKSTRA &, 531 & ,074 & ,689 & 7,185 &, 000 & 1,000 & 1,000 \\
\hline \multirow[t]{3}{*}{2} & (Constant) & 4,488 & 917 & & 4,895 & ,000 & & \\
\hline & LAKSTRA & ,419 & ,077 & ,545 & 5,479 & ,000 & 799 & 1,252 \\
\hline & EVASTRA & ,352 & 108 & ,323 & 3,246 & ,002 & ,799 & 1,252 \\
\hline \multirow[t]{4}{*}{3} & (Constant) & 4,553 & 878 & & 5,185 & ,000 & & \\
\hline & LAKSTRA & ,437 & ,074 & ,568 & 5,937 & ,000 & ,791 & 1,264 \\
\hline & EVASTRA & ,348 & 104 & ,319 & 3,352 & ,001 & ,798 & 1,253 \\
\hline & 10-99 ORANG &,- 778 & ,315 &,- 211 & $-2,470$ & ,017 & ,990 & 1,011 \\
\hline \multirow[t]{5}{*}{4} & (Constant) & 3,911 & ,866 & & 4,514 & ,000 & & \\
\hline & LAKSTRA & ,457 & ,070 & ,593 & 6,509 &, 000 & ,782 & 1,279 \\
\hline & EVASTRA & ,363 & ,099 & ,333 & 3,687 & ,001 & ,796 & 1,257 \\
\hline & 10-99 ORANG &,- 958 & ,306 &,- 260 & $-3,128$ & ,003 & ,942 & 1,061 \\
\hline & $25-40$ &, 761 & ,284 & ,223 & 2,679 & ,010 & ,935 & 1,070 \\
\hline \multirow[t]{6}{*}{5} & (Constant) & 3,704 & ,846 & & 4,380 & ,000 & & \\
\hline & LAKSTRA & ,377 & ,078 & ,489 & 4,834 & ,000 & ,597 & 1,676 \\
\hline & EVASTRA & ,265 & ,106 & ,243 & 2,496 & ,016 & ,644 & 1,554 \\
\hline & 10-99 ORANG & $-1,001$ & 297 &,- 272 & $-3,366$ & ,001 & ,938 & 1,067 \\
\hline & $25-40$ &, 752 & ,275 & ,221 & 2,732 & ,009 & ,934 & 1,070 \\
\hline & RENSTRA & 166 & ,079 & ,235 & 2,116 & ,039 & ,496 & 2,016 \\
\hline
\end{tabular}

a. Dependent Variable: KINERJA 


\section{Result and Discussion}

Of the 158 respondents dominated by men with a percentage of $66.46 \%$, while women only amounted to $33.54 \%$. Based on the age, the respondents are predominantly productive age, such as $25-40$ years as many as 83 people $(52.53 \%)$ and age $41-50$ years as many as 51 people $(32.28 \%)$. In regards to the educational level, respondents are dominated by bachelor and senior high school with a percentage of $45.57 \%$ (72 people) and $34.18 \%$ (54 people) respectively. The long standing of SME owned by respondents surveyed is very varied with very small difference. The age of SME 6-10 years ranks first with 49 units (31\%), followed by $11-15$ years as many as 40 units $(25.32 \%)$, then the age of SMEs over 15 years as many as 35 units $(22.15 \%)$, and SME aged 3-5 years as many as 34 units $(21.52 \%)$. Finally, by size, small-sized enterprises (5-9 employees) is 91 units $(57.59 \%)$, and medium-sized (10-99 employees) is 67 units (42.41\%). This characteristic indicates that the SME in Makassar have considerable potential to grow and develop, as the dominant SME owners are productive (25-40 years and 41-50 years old), and the educational level of majority SME owners is bachelor and senior high school graduates.

Prior testing the above nine hypotheses, the validity, reliability, autocorrelation, and multicolonoerity tests of items related to each dependent variable, such as sales volume, break even point (BEP), and profit must be conducted. The test results show that the whole data (which is not of the dummy variable) are valid because its have a correlation coefficient which is $>0.3$, and reliable because its reliability value $>0.60$. Similarly, there is no autocorrelation between the data on the dependent variable because its Durbin-Watson value is between -2 and +2 , and there is no multicolonoerity because its VIF value is $<10$. Because the data has fulfilled the validity, reliability, autocorrelation, and multicolinearity requirement, then it can be concluded that the questionnaire used to measure the dependent variable (sales volume, BEP, and profit) is feasible used to measure the effect of the independent variables on the dependent variables.

The testing result of hypothesis 1 which states that strategic management practices have a significant effect on SME sales volume indicates that the strategic planning and strategy implementation in medium-sized enterprises have significant effect on sales volume. This indicates that the role of strategic planning and strategy implementation in medium-sized enterprise is very urgent to achieve sales volume. While in small-sized enterprises, there is no difference in achieving sales volume, neither formulate strategic management and strategy implemention nor ignore these two strategic management practices.
The testing result of the hypothesis 1a show that the medium-sized enterprises moderate between the the strategy implementation and sales volume, while company size (small and medium-size) does not moderate between strategic management practices (as a whole) and sales volume. Similarly, the testing result of hypothesis $1 \mathrm{~b}$ shows that the level of education does not moderate between the strategic management practices and sales volume.

The testing result of the hypothesis 2 which states that strategic management practices have significant effect on the acceleration of SME breakeven point (BEP) achievement shows that the strategic planning and strategy evaluation (two strategic management practices) have significant effect on the acceleration of break even point (BEP) achievement. This result shows that to accelerate SME's BEP achievement it is necessary for the SME owners to arrange strategic planning earlier and then evaluate its business strategy implementation. An important emphasis on strategic planning and strategy evaluation indicates that when SME want to achieve BEP in 1 year or less, both strategic management practices should be more concerned than other strategic management practices.

The testing result of the hypothesis $2 \mathrm{~b}$ shows that the firm size does not moderate between strategic management practices and firm profit. Likewise the testing result of hypothesis $2 \mathrm{~b}$ show that the level of education does not moderate between strategic management practices and firm profit.

The testing result of hypothesis 3 which states that strategic management practices have significant effect on the achievement of SME profit indicates that strategic planning and strategy implementation have significant effect on the achievement of firm profit. This implies that both strategic management practices hold an important role for SME in achieving tehir targeted profit.

The testing result of hypothesis 3 a shows that the firm size does not moderate between strategic management practices and the accelaration of break even point (BEP) achievement. Similarly, the testing result of hypothesis $3 \mathrm{~b}$ shows that the educational level does not moderate between strategic management practices and the accelaration of break even point (BEP) achievement.

Based on the hypothesis testing results, the research results can be shown in the following figure (Figure3):

The research findings are consistent with a number of research findings from [6] as well as consistent with research results by [3], who states that the key aspects of strategic planning include environmental analysis, corporate mission setting, strategy formulation, strategy execution, strategy evaluation and control have important roles in maintaining and improving company performance. 


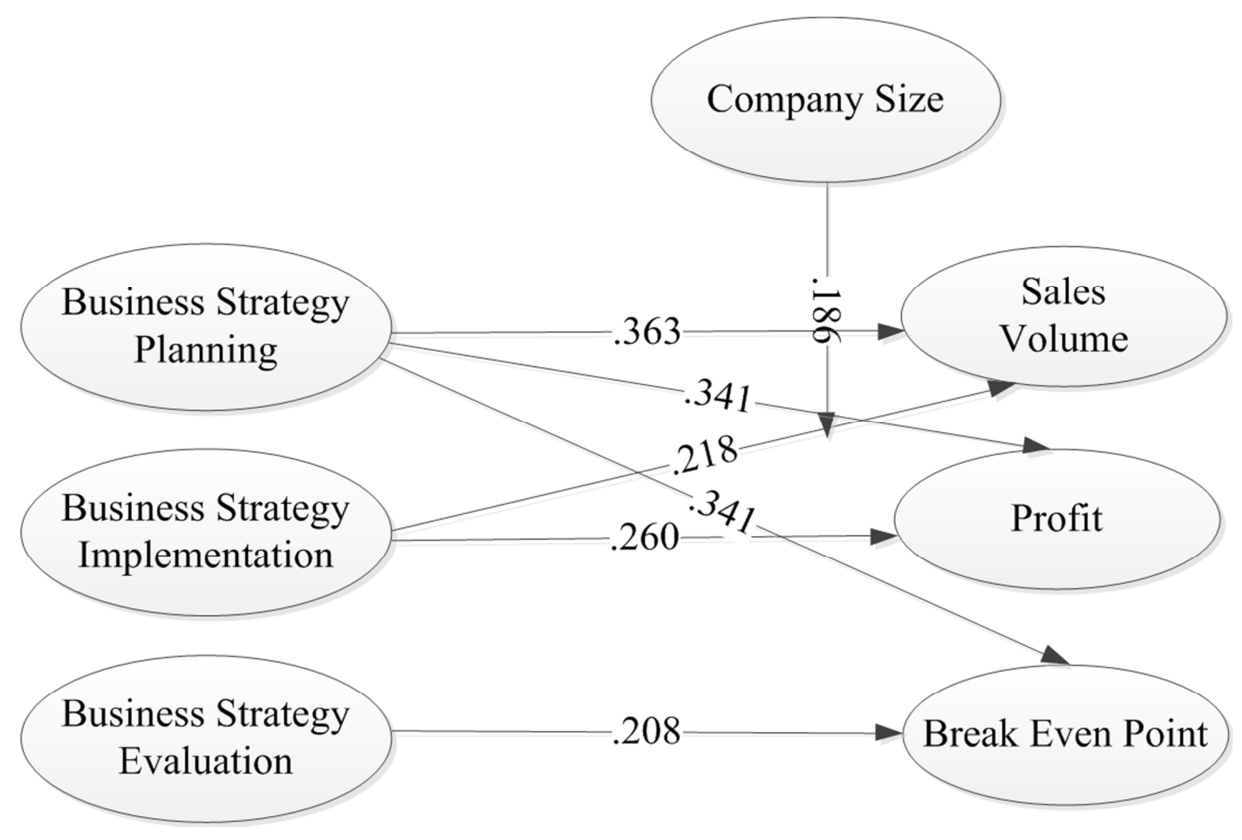

Figure 7. Research results.

\section{Conclusion and Recommendations}

Based on the hypothesis testing results and on the research discussion, it can be concluded that the role of strategic planning, strategy implementation, and strategy evaluation, especially in the medium-sized companies are essential in achieving sales volume, accelerating BEP achievement, and achieving targeted profit. While the determination of mission and strategy formulation do not significantly affect the achievement of the three SMEperformances. This research also found that the educational level of SME owners does not moderate between strategic management practices and company performances. Therefore, it is very important for SME's owners, especially for middle-sized enterprises (10 99 employees) to conduct strategic planning, implement and evaluate it regularly in order to achieve targeted sales volume, increase acceleration of even point brek (BEP) achievements and achieve targeted profit in accordance with the capacity of SME. This research contributes to the SME's owners (managers) and SME stakeholders in order to achieve better marketing performance (sales volume) and financial performance (BEP and profit) in the future.

\section{References}

[1] Andersen, T. J. (2000). Strategic planning, autonomous actions and corporate performance. Long Range Planning, 33, 184-200.

[2] Falshaw, J. R., Glaister, K. W., \& Tatoglu, E. (2006). Evidence on formal strategic planning and company performance. Management Decision Journal, 44 (1), 9-30.

[3] David, Fred R \& David, Forest R. 2016. Manajemen Strategik: Suatu Pendapatan Keunggulan Bersaing. Edisi ke15. Jakarta: Salemba Empat.
[4] Odame, A. M. (2007). The relevance of strategic planning for entrepreneurial businesses in South Africa. (Master of Business Administration dissertation). University of Pretoria.

[5] Huang, C. J. (2006). Strategic planning and dysfunction: The dark side of mandating a formal planning system. Soochow Journal of Political Science, 22, 47-71.

[6] Dincer, O., Tatoglu, E., \& Glaister, K. W. (2006). The strategic planning process: Evidence from Turkish firms. Management Research News, 29 (4), 206-219.

[7] O'regan, N., \& Ghobadian, A. (2004). The importance of capabilities for strategic direction and performance. Management Decision, 42 (2), 292-312.

[8] Bordean, O. N., Borza, A., dan Segura, D. G. (2011). A comparative approach of the generic strategies within the hotel industry: Romania VS. USA. Management and Marketing Challenges for the Knowledge Society. Vol. 6 (4), 501-514.

[9] Parnell, J. A., Lester, D. L. Long, Z., dan Koseoglu, M. A. (2012). How environmental uncertainty affects the link between business strategy and performance in SMEs Evidence from China, Turkey, and the USA. Management Decision, 50 (4), 546-568.

[10] Ansoff, H. I., dan Bradenburg, G. R. (1971). A language for organization design. Management Science, 17, 705-731.

[11] Andrews, K. R. (1967). The concept of corporate strategy (3rd ed.). Homewood, IL: Irwin.

[12] Barney, J. B., dan Clark, D. N. (2007). Resource-based theory: Creating and sustaining competitive advantage. UK: Oxford University Press.

[13] Porter, M. E. (1980). Competitive strategy: Techniques for analyzing industries and competitors. New York: Free Press.

[14] Mason, E. S. (1939). Price and production policies of large scale enterprises. American Economic Review, 29, 61-74. 
[15] Bain, J. S. (1968). Industrial Organization (2 ed.). New York: Wiley.

[16] Analoui, F., dan Karami, A. (2003). Strategic Management in Small and Medium Enterprises ( $1^{\text {st }}$ ed.). London: Thomson Learning.

[17] Hill, C. W. L., dan Jones, G. R. (1995). Strategic Management Theory: an Integrated Approach. ( $3^{\text {rd }}$ ed.). Texas, USA: Texas $A$ and $M$. University.

[18] Chen, M. (1996). Competitor analysis and interfirm rivalry: Toward a theoretical integration. Academy of Management Review, 21 (1), 100-134.

[19] Grant, R. M. (1998). Contemporary strategy analysis (3rd ed.). Malden, Massachusetts: Blackwell Publishers Ltd.

[20] Wheelen, T. L., dan Hunger, J. D. (2001). Strategic Management and Business Policy (7th ed.). New Jersey: Prentice-Hall.

[21] Pearce, J. A., dan Robinson, J. R. (2009). Strategic Management: Formulation, Implementation and Control (11th Ed.). New York: The McGraw-Hill Companies, Inc.

[22] Tang, T., \& Zhang, Y. (2005). Marketing strategy and business performance of small construction firms in China. Macquarie Graduate School of Management working papers in management: 1-12. March. 50.

[23] Punn, K. F., \& White, A. S. (2005). A performance measurement paradigm for integrating strategy formulation: A review of systems and frameworks. International Journal of Manage ment Reviews, 7 (1), 49-71.

[24] Chow, C. W., \& Van Der Stede, W. A. (2006). The use and usefulness of nonfinancial performance measures. Management Accounting Quarterly, 7 (3), 1-8.

[25] Panigyrakis, G. G., \& Theodoridis, P. K. (2009). Internal marketing impact on business performance in a retail context. International Journal of Retail and Distribution Management, 37 (7), 600-628.

[26] Phillips, P., Davies, F., \& Moutinho, L. (2000). The interactive effects of strategic planning on hotel performance: a neural network analysis. Management Decision Journal, 37 (3), 279288 .

[27] Chong, H. G. (2008). Measuring performance of small-andmedium sized enterprises: the grounded theory approach. Journal of Business and Public Affairs, 2 (1), 1-10.

[28] Verbeen, F. H. M., \& Boons, A. N. A. M. (2009). Strategic priorities, performance measures and performance: An empirical analysis in Dutch firms. European Management Journal, 27, 113-128.

[29] Lema, D. G. P., Cortes, E. A., Lizano, M. M, dan Ochovo, R. B. (2012). Strategy, competitive factors and performance in small and medium enterprise (SMEs). African Journal of Business Management, 6 (26), 7714-7726.

[30] Omsa, S., Salim, U., Djumahir, Rahayu, M. (2015). Competitive Strategi Orientation and Company Performance in Selected SMEs Wooden Furniture in Pasuruan City. International Journal of Applied Business and Economic Research (IJABER). Vol. 13, No. 7. 4659-4676.

[31] Sum, C., Jukow, L., \& Chen, S. (2004). Taxonomy of operations strategies of high performing small and medium enterprises in Singapore. International Journal of Operations and Production Management, 24 (3), 321-345.

[32] Phillips, P. (2000). The strategic planning/finance interface: Does sophistication really matter? Management Decision, 38 (8), 541-549.

[33] Naidoo, K. K. (2006). The strategic processes of small businesses operating in a turbulent environment: A retail community pharmacy perspective. (Doctor of Business Leadership Dissertation). University of South Africa. Pretoria.

[34] Laljit, C. R. (2006). The business strategy development among SMEs in the Kwa-Zulu Natal clothing manufacturing sector. (Master of Business Administration dissertation). Durban University of Technology. Durban.

[35] Murimbika, M. (2011). Influence of strategic management practices on the entrepreneurial orientation of South African firms in the financial and business services sectors. (Masters Dissertation). University of Witwatersrand. Johannesburg.

[36] Nkulu, M. (2012). The use of strategic planning for small, medium and micro enterprises in the retail industry. (Master of Commerce Dissertation). University of Johannesburg. Johannesburg.

[37] Mohutsiwa, M. (2012). Strategic entrepreneurship and performance of SMEs in South Africa. (Master of Management Dissertation). University of Witwatersrand. Johannesburg.

\section{Biography}

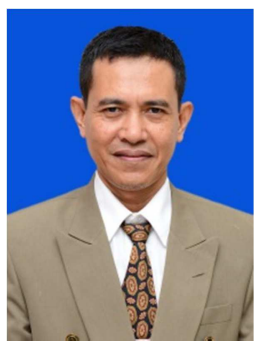

Sirajuddin Omsa is a lecturer in the State Polytechnic of Ujung Pandang (SPUP), Makassar, Indonesia. $\mathrm{He}$ works at the Accounting Department. In the SPUP, he teaches Strategic Management and Corporate Policy, Financial Management, Business Management, Micro and Macro Economics, and Business Budgetting. He has published several articles in academic journals in International Journal of Applied Business and Economics Research (IJABER), Science Journal of Business and Management (SJBM), and in Management and Administrative Science Review (MASR). He took his bachelor degree in Hasanuddin University (Indonesia), master degree in Flinders University (Australia), and $\mathrm{PhD}$ in Brawijaya University (Indonesia).

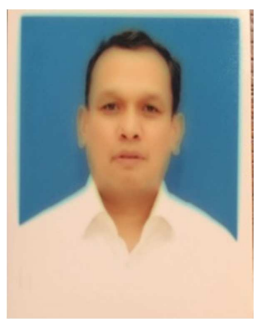

Muhammad Ridwan is a lecturer in the Accounting Department, State Polytechnic of Ujung Pandang (SPUP), Makassar, Indonesia. In the SPUP, he teaches Strategic Management and Corporate Policy, Organizational Behavior, Public Accounting, Financial Management, and Financial Accounting. He has published several articles in academic journals in Economic Journal of the Economic Faculty, Hasanuddin University and in JASSA Finsia's quarterly Journal of Applied Finance. His bachelor degree was taken in Hasanuddin University, master degree in Newcastle University (Australia), and $\mathrm{PhD}$ in University of Indonesia (UI). 


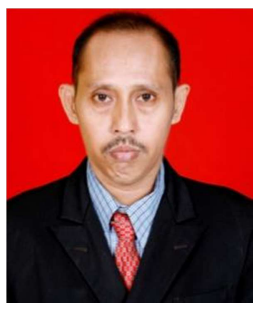

Muhammad Jayadi is a lecturer in the Accounting Department, State Polytechnic of Ujung Pandang (SPUP), Makassar, Indonesia. His subjects are Database Computer Application, Financial math, Descriptive and Inferencial Statistic, and Spreadsheet Computer Application. He has conducted research entitled Financial Report Module Design for Small and Medium Enterprises (SME), and Marketing Mix Strategy for Bread companies in Maros. He took his bachelor degree in Math and Exact Science Faculty in Hasanuddin University (Indonesia), and master degree in Sepuluh November Technology Institute (ITS) Surabaya (Indonesia). 